\title{
WESTERN DEPENDENCE ON OIL
}

\begin{abstract}
WARNING that Britain's dependence on oil has become "potentially dangerous to our national economy" is made by the 11,000 strong Association of Scientific Workers in a 'policy statement' in a new publication entitled $A$ National Fuel and Power Policy*.

The recommendations in this statement are put forward in the form of a twelve-point plan that has as a main objective improved co-ordination and development of the national resources of fuel and power. The objectives are worthy ones, and are set out in an attractive manner with some sound supporting arguments, but some of the means to be employed in the plan are open to question on the grounds of practicability.

The first point made is that the efficiency of the production of coal should continue to be improved with the view of making coal cheaper in real terms. For this purpose increased expenditure on scientific research is rightly regarded as necessary, but, in the subsequent recommendations, difficult and almost intangible problems are raised as to the maintenance of markets over fixed periods, the subsidizing of specific uses of coal, the 'firm basing' of the generation of electricity on coal and back-pressure generation by industry and much additional planning. Several of the suggestions made for controlling the balance of fuels and the types of appliance installed embody a measure of compulsion either by legal requirements or by discriminatory taxation. There is nothing intrinsically against this, though it is clearly contrary to the present Government's policy. Attempts to control markets in the manner suggested are not necessarily in the national interest, nor do they actually work out in the manner intended in practice. The back-pressure generation of power in industry is only economical if the individual circumstances of the case in point are favourable. Each set of circum. stances becomes almost a law unto itself, and sweeping decisions as to their application in general cannot
\end{abstract} be made.

As regards the recommendation for the formation of a National Coal Chemical Board, it is not clear what advantages would accrue from yet another national board in a relatively small field of activity.

Concerning the needed improvements in research and development in the mining, utilization, and marketing of coal, controversy may well arise. Thus it is perhaps surprising to read that it may be necessary to abandon the conception of the British Coal Utilization Research Association as the National Coal Board's agent in the field of coal utilization, for it seems perfectly clear that the National Coal Board has always interpreted literally its remit under the Nationalization Act as "making supplies of coal available, of such qualities and sizes, in such quantities and at such prices, as may seem to them best calculated to further the public interest in all respects ..."; in other words, utilization has not been the National Coal Board's responsibility under the Act; in fact the support given to the British Coal

- A National Fuel and Power Policy: a Policy Statement by the Association of Scientific Workers. Pp. 20. (Iondon: Association of Scientific Workers, 15 Half Moon Street, W.1, 1960.) 18.
Utilization Research Association has been somewhat incidental. In point of fact this support has approximated to $£ 140,000$ per annum since nationalization, the overall income of the British Coal Utilization Re-

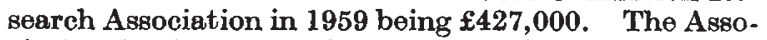
ciation is thus operating on a much broader front than is implied in the statement of the Association of Scientific Workers. This research work covers contract work for the Atomic Energy Authority as well as that for the Ministry of Power. As regards the latter, the contract work on the slagging gasifier, as well as other features of the research programme, received commendation in the recent report of the Wilson Committee on Coal Derivatives. Further, the Association's real potential for work in coal utilization on a broad front was indicated, given adequate financial support.

It is not realized fully, perhaps, by the public that scientific work on the winning, preparation and use of coal requires an array of top-level scientists and technologists not yet even contemplated ; moreover, to attract such personnel to-day to an industry in disfavour with the public mind will necessitate a radical change of approach. The expenditure on research by the National Coal Board, as given in the Wilson Report, was $£ 2,427,300$ in 1959 , its turnover, $£ 850$ million, that is, approximately 0.29 per cent.

Cogent criticism is devoted to the world role of the oil industry, which is regarded as an international one dominated by a few large producers with pricefixing arrangements "typical of a cartel". "In Western Europe the price of oil and refined products has been below internationally arranged prices", the statement declares, and this increasing dependence in Western European countries on oil has made them vulnerable to price increases which would "adversely affect our position in world markets since fuel costs are a significant part of production costs". This may be true, but the question is not answered as to whether a manufacturer who finds the use of oil more economical than alternative fuels, mainly the derivatives of coal, should hold off conversion of his plant to oil because of this possibility. It is, however, evident from the arguments put forward that the challenge of oil can mainly be met by a substantial increase in technological activity in respect of coal.

A point of considerable interest is made as regards the inflexibility of the fuel oil/petrol ratio of refinery production in Britain. Thus Britain imports 73 per cent of its oil as crude oil, and this is refined so as to yield 27 per cent motor- and aviation-spirit, and 43 per cent fuel oil and other products such as paraffin. Refining could be adjusted, as in the United States, to yield 50 per cent of petrol and 17 per cent fuel oil. Such a change in refinery technique in Britain would result in British petrol requirements being met by half the present import of crude oil. Again, the trend towards oil is largely based on the comparison between modern oil-fired appliances and obsolete hand-fired coal-burning appliances. The advantages of oil-burning are certainly sometimes more apparent than real. What would be the position if a cheap industrial gas made by total gasification from coal 
were made available? The advocacy of this development is strongly supported; indeed a call is made for a higher priority in the pursuit of this subject. It is believed, too, that industry would be bound to respond to its solution for manifold reasons. Taking the long view, as regards the future of the coal fields, this could well be an almost universal method for the utilization of coal, for it is the only foreseeable solution at present of the sulphur problem.

R. J. SARJANT

\section{BIOCHEMISTRY OF HUMAN TUMOURS}

$\mathrm{D}^{\mathrm{n}}$ URING November 17-19, an international con. ference on the biochemistry of human tumours was held at the University of Wisconsin, Madison. This meeting was sponsored by the Biochemistry Committee of the Cancer Chemotherapy National Service Center, National Cancer Institute, U.S. Public Health Service, with the present writer serving as programme chairman. Those invited to attend included five scientists from Europe and fifty-five from the United States. Among these were pathologists, clinical cancer chemotherapists, biochemists and biologists. The need for this conference arose from the conviction of members of the $T$,iochemistry Committee, expressed in a guest editr rial (James F. Holland and Charles Heidelberger, Human Cancer, the Primary Target", Cancer $\Gamma_{v}$ search, 20, 975-6 ; 1960), that despite formidable technical difficulties, increased biochemical research must be carried out on human tumours. This should include studies on the enzyme patterns of human tumours as compared with normal tissues, as well as research on the metabolism and mechanism of action of active tumourinhibitory drugs in the human cancer patient and in vitro with specimens obtained at surgery or by biopsy.

The meeting was opened by James F. Holland (Buffalo, U.S.A.), who pointed out some of our major deficiencies in knowledge about human cancer. $\mathrm{He}$ directed attention to the variability of human tumours, even of the same kinds, with respect to growth-rates and patterns, and to their response to chemotherapeutic agents. Even though extensive work has been done on biochemical mechanisms of action of various antimetabolites in susceptible and resistant transplanted rodent tumours, similar work on human tumours is almost totally lacking. Moreover, there is little information on enzyme activity in human tumours, and on the effects of tumours on host metabolism, as exemplified by terminal cachexia. Holland felt there is a particular need to develop new methods to measure the growth-rates of inaccessible tumours and to get a measure of the amount of stromal and necrotic contamination of tumour specimens.

A brief review of human tumour pathology was given by Paul Kotin (Los Angeles), who showed a number of slides to illustrate diversity even among similar types of human tumours. He made the point that there is little, if any, correlation between the histological appearance of tumours and the carcinogenic stimuli that produced them. Therefore, he suggested that biochemical patterns reflecting essential consequences of the carcinogenic process might be studied more meaningfully in pre-neoplastic tissues, such as carcinomas in situ, rather than in the fully developed and highly diversified tumours. He also suggested that work be carried out to understand the differences in natural history between certain tumours in children and their counterparts in the adult. The morphological considerations were carried to another order of resolution by Francoise Haguenau (Paris), who discussed the electron microscopy of human tumours. She demonstrated with elegant slides the diversity of human tumours with respect to the appearance of the submicroscopic cellular organelles. Furthermore, some cells that appeared similar in the light microscope were found to differ markedly in their ultramicroscopic morphology, and she was able to distinguish on this basis between the $\alpha$ - and $\beta$-cells of Caspersson.

A. R. Curreri (Madison) discussed the surgeon's role in the collection of surgical specimens, and emphasized the willingness of surgeons to collaborate in co-operative enterprises provided that the purpose of the research was made clear. Much discussion followed, which was summarized by Holland : "Know thy surgeon and love thy biochemist".

A detailed discussion of the techniques that have been developed for low-temperature storage, with maintenance of viability, of cells grown in tissue culture was given by Cyril Stulberg (Detroit). The application of these methods to the storage of sections of humen tumours, which would be essential in any proposed large-scale co-operative studies of tumour enzymology, remains to be worked out.

Because of the extreme heterogeneity of specimens of human tumours, it is clear that micro- and ultramicro-methods are required in most cases in order to obtain meaningful information. Accordingly, David Glick (Minneapolis) and Oliver Lowry (St. Louis) discussed in some detail the elegant and precise techniques that they have developed for the quantitative assay of enzymes extracted from samples the size of common histological sections and by microdissection. These involved mainly colorimetric, spectrophotometric, and fluorimetric methods. Another technique for enzyme assays with very small samples was described by V. R. Potter (Madison), involving the use of labelled substrates of high specific activity, paper chromatography, and the use of automatic recording equipment for the direct determination on the paper strip of the radioactivity in the substrate and product.

His extensive work on the amounts of some twenty enzymes in 800 human tumours by various histological staining methods was described by R. G. J. Willighaghen (Leyden). An enormous diversity of results was found; some enzymes were present in some tumours and absent in others from the same organ and of the same histological type. However, in some cases it has been possible to predict the clinical behaviour of tumours based on histochemical observations. Using similar techniques, L. Wattenberg (Minneapolis) reported that aminopeptidase, an enzyme not found in the normal gastric mucosa, occurs in many gastric malignancies, and in this 